\title{
Development and Evaluation of a Self Propelled Pulse Reaper
}

\author{
Shibanee Maharana*, A.K. Goel, D. Behera and M. Mahapatra \\ College of Agricultural Engineering \& Technology, Orissa University of Agriculture and \\ Technology, Bhubaneswar, Odisha, India \\ *Corresponding author
}

\section{A B S T R A C T}

\section{Keywords}

Harvesting, Pulse, Efficiency, Speed, Variety

\section{Article Info}

Accepted:

15 October 2018

Available Online:

10 November 2018
A power operated pulse reaper was developed at OUAT, Bhubaneswar and evaluated in farmer's field for harvesting green gram. The performance of the developed reaper was studied for 3 different varieties of green gram namely OUM-11-5, PDM-54 and Local at three machine speed $(1.8,2.3$ and $2.8 \mathrm{~km} / \mathrm{h})$. The highest effective field capacity of 0.248 $\mathrm{ha} / \mathrm{h}$ was observed at $2.8 \mathrm{~km} / \mathrm{h}$ speed while the lowest of $0.161 \mathrm{ha} / \mathrm{h}$ at $1.8 \mathrm{~km} / \mathrm{h}$ for the local variety. The highest field efficiency was found to be $81.38 \%$ for OUM-11-5 variety at $2.8 \mathrm{~km} / \mathrm{h}$ speed while lowest field efficiency was $78.61 \%$ for PDM-54 at the same speed of $2.80 \mathrm{~km} / \mathrm{h}$. The cost of harvesting with this machine was found to be Rs 625/ha as compared to Rs 3100 /ha in traditional method of manual harvesting by using local sickle and Rs 5000/ha by manual uprooting.

\section{Introduction}

Pulses are major sources of proteins for the vegetarians in India and complement the diet with essential amino acids, vitamins and minerals. India is the largest producer and consumer of pulses in the world. Though India is the world's largest producer of pulses, it also imports a large quantity of pulses to meet the growing domestic needs. During 2009-10, India imported 3.5 million tons of pulses from the countries like Australia, Canada, and Myanmar (Gowda et al., 2013). It has been estimated that India's population would reach 1.68 billion by 2030 from the present level of 1.21 billion. Accordingly, the projected pulse requirement for the year 2030 is 32 million tons with an anticipated required growth rate of $4.2 \%$ (Anonymous, 2013). India has to produce not only enough pulses but also remain competitive to protect the indigenous pulse production. In view of this, India has to develop and adopt more efficient crop production technologies along with the favorable policies to encourage farmers to bring more area under pulses.

About 70\% population depend on agriculture in Odisha. The total cultivated area of the state is about 61.80 lakh hectares out of which pulse is grown in 20.03 lakh hectares and recorded as the $2^{\text {nd }}$ highest cultivated area under pulse crop followed by paddy. It has been observed that, production of pulses in the state has decreased from 266.0 to 247.0 MT and the cultivated area decreased from 6.01 to 
5.51 lakh ha during the period of 2002-03 to 2011-12 respectively (Anonymous, 2013). Acute shortage of labour at the harvesting time and non-availability of appropriate machines for various operations is the major cause for reduction in overall cultivated area as well as under the pulse production in the recent years in the state of Odisha. Generally, pulses are harvested by manual uprooting the whole plants which is very tedious and time consuming process. The manpower requirement for uprooting of green gram / black gram in conventional method is about 200-240 man-hours per hectare (Maharana, 2015). Now-a-days sufficient manpower is not available in rural areas as the rural youths are migrating to urban areas for alternative more economically lucrative jobs. It is observed that, in some areas uprooting of this crop is carried by contract labours at 50 to $60 \%$ of the produce value (by volume basis of uprooted plant) towards the wages for uprooting and transporting. Due to these problems, farmers are no more interested to grow pulses. Hence, a pulse reaper has been developed for harvesting pulse crops that will reduce the cost of harvesting as well as human drudgery involved in uprooting of pulse crop stalks.

\section{Materials and Methods}

A small horse power engine operated pulse reaper was developed in College of Agricultural Engineering and Technology, OUAT, Bhubaneswar.

\section{Development of pulse reaper}

On the basis of preliminary studies conducted on cutting force requirement of green gram stems by the relation given by Srivastava, et al., (2006), Universal Testing Machine (5 tonne capacity) and taking into account the rolling resistance and tractive force, the power requirement for the pulse reaper was selected as follows. the power requirement for cutting green gram stems, power for traction, frictional losses were considered. Sample of the green gram and black gram stems were cut from the ground level and brought to the laboratory in sealed plastic packets and were tested on the same day. Black gram variety of T 9 and green gram variety of PDM 54 were collected. One cutter bar blade was mounted on the upper fixture of the Universal Testing Machine (UTM) and the lower jaw was fixed in such a way that, stem can be cut by the blade by shearing action. Moisture content and diameter of each stem was taken and the force required to cut the stems were recorded.

A commercially available $\mathrm{Z} 170 \mathrm{~F}$ diesel engine having power $3.94 \mathrm{hp}$ @ $2600 \mathrm{rpm}$ has been selected for the pulse reaper with $1.2 \mathrm{~m}$ cutter bar. The developed pulse reaper is a walk behind type reaper with a handle mounted at the right side of the machine for steering. A gear box with 3 forward and one reverse speed was used with the help of suitable gear reducing system. The machine is provided with 2 pneumatic wheels for its movement in the field (Fig. 1). Power is transmitted to both wheels from the engine by chain drive. The fabrication, operation and adjustment of the machine are made simple so that a farmer can operate and maintain the machine.

\section{Evaluation of developed reaper}

The developed pulse reaper was evaluated in a farmer's field at Mukulishi of Balasore district (Fig. 2). The cutter bar was operated at 4 different speeds of 690, 760, 840 and 930 strokes/min. The result was highly satisfactory at a cutter bar speed of 840 strokes/min and hence for the entire evaluation process, cutter bar speed was fixed at 840 strokes/min. Due to the suitable arrangement in gear box, machine was operated at 3 different speeds of 1.8, 2.3 and $2.8 \mathrm{~km} / \mathrm{h}$. The parameters like pre-harvest 
loss, header losses and field capacity were measured during evaluation.

\section{Break even point}

Break-even point of the seeder is expressed in term of area that should be seeded by the seeder annually so that the cost of direct seeding per hectare equals to that of manual direct seeding per hectare. It was calculated by using the following relationship (Manian $e t$ al., 1987 and Singh et al., 1983).

Break-even point, ha =

$\frac{\text { Annual fixed cost }}{\text { Cost of harvesting /ha-Variable cost/ ha }}$

\section{Payback period}

Payback period is the time needed to recoup the total money invested for the machine. It was calculated from the following relationship.

Payback period $=$

Total investment

Annual cost of manual harvesting -Annual cost of machine harvesting

\section{Cost of operation}

Cost of operation of developed pulse reaper was calculated on hourly basis and subsequently converted into cost per hectare taking into account the field capacity.

\section{Results and Discussion}

The developed pulse reaper was evaluated for harvesting of green gram at farmers field at village Mukulish, Balasore during Rabi 2015. Three varieties such as OUM-11-5, PDM-45 and local variety were harvested by the reaper. The machine was operated at three different forward speeds of 1.80, 2.30 and $2.80 \mathrm{~km} / \mathrm{h}$ for each variety and the pod losses were measured. The observations like pre-harvest loss, un-harvested loss, shattering loss, speed of operation and actual field capacity at each level of speed for each variety were recorded and presented below (Table 1).

\section{Effect of speed on pod losses}

The effect of speed on pod loss of three varieties of green gram were studied and presented in Table 2. It is found that the pod loss increased with increase in speed from 1.8 to $2.8 \mathrm{~km} / \mathrm{h}$ for all the three varieties (Fig. 3). The highest pod loss of $2.40 \%$ was recorded for local variety at $2.80 \mathrm{~km} / \mathrm{h}$ while the lowest pod loss (1.63\%) was observed for OUM 11-5 at a speed of $1.80 \mathrm{~km} / \mathrm{h}$. The higher pod loss of local variety at higher speed may be due to its susceptibility to shattering which is seen from the higher percentage of pre-harvest losses of this variety. Also higher loss may be attributed due to higher vibration of plants at higher machine speed.

The ANOVA of effect of speed and variety on pod loss is presented in Table 3. It is seen that the effect of speed on pod losses are highly significant and also the varieties have significant effect on pod loss.

Effect of speed on performance of the pulse reaper

The performance of the pulse reaper was studied for different varieties at three levels of speed ranging from 1.80 to $2.80 \mathrm{~km} / \mathrm{h}$ and presented in Table 4. It is observed that the highest effective field capacity of $0.248 \mathrm{ha} / \mathrm{h}$ was with the local variety at $2.80 \mathrm{~km} / \mathrm{h}$ speed while the lowest field capacity of $0.161 \mathrm{ha} / \mathrm{h}$ at $1.80 \mathrm{~km} / \mathrm{h}$ speed for the same variety. The highest field efficiency of $81.38 \%$ was found to be with OUM- $11-5$ at $2.30 \mathrm{~km} / \mathrm{h}$ speed while the lowest field efficiency of $78.61 \%$ was with PDM-54 variety at $2.80 \mathrm{~km} / \mathrm{h}$ speed. The higher field capacity for local variety may 
be due to the ease of operation of the machine due to lower stem diameter of the variety. In general, highest field efficiencies were observed at $2.3 \mathrm{~km} / \mathrm{h}$ forward speed for all the three varieties and hence, effect of varieties and moisture content on pod losses was studied at $2.3 \mathrm{~km} / \mathrm{h}$ forward speed.

\section{Effect of variety on pod loss}

The effect of varieties on pod losses at 2.30 $\mathrm{km} / \mathrm{h}$ forward speed of machine was studied and is presented in Table 5. The highest pod losses ranging from 0.96 to $2.23 \%$ were observed for local variety as the speed varied from 1.80 to $2.80 \mathrm{~km} / \mathrm{h}$ and this may be due to its higher susceptibility to shattering. The lowest pod losses of 0.79 to $1.71 \%$ were observed for OUM-11-5 variety and this may be due to its characteristic capability to withstand higher vibration.

Table.1 Specification of pulse reaper

\begin{tabular}{|c|c|c|}
\hline SI No & Parameters & Values \\
\hline 1. & Type & Walk behind type \\
\hline \multirow[t]{4}{*}{2.} & Overall dimensions, $\mathrm{mm}$ & \\
\hline & Length & 2300 \\
\hline & Width & 1500 \\
\hline & Height & 1100 \\
\hline 3. & Weight, kg & 149 \\
\hline \multirow[t]{4}{*}{4.} & Handle & \\
\hline & Material and size & MS pipe, $25 \mathrm{~mm}$ dia \\
\hline & Position & RHS of reaper \\
\hline & Spacing between handle bar, mm & 580 \\
\hline \multirow[t]{4}{*}{5.} & Blade & \\
\hline & Type & Serrated \\
\hline & Material & High carbon steel \\
\hline & Number & 16 \\
\hline \multirow[t]{3}{*}{6.} & Cutter bar & \\
\hline & Length, mm & 1200 \\
\hline & No. of double finger attached & 8 \\
\hline \multirow[t]{6}{*}{7.} & Engine & \\
\hline & Model & $\mathrm{Z} 170 \mathrm{~F}$ \\
\hline & Power, kW (hp) & $2.94(3.94)$ \\
\hline & RPM & 2600 \\
\hline & Fuel used & Diesel \\
\hline & Cooling system & Air cooled \\
\hline \multirow[t]{3}{*}{8.} & Gear box & \\
\hline & No. of forward gear & 3 \\
\hline & No. of reverse gear & 1 \\
\hline \multirow[t]{3}{*}{9.} & Wheels & \\
\hline & Type & Pneumatic \\
\hline & Size & $4.5-19$ \\
\hline
\end{tabular}


Table.2 Effect of variety and speed on pod loss

\begin{tabular}{|c|c|c|c|}
\hline SI.No & Variety & Speed of operation, $\mathrm{km} / \mathrm{h}$ & Pod loss, \% \\
\hline \multirow[t]{3}{*}{1} & \multirow[t]{3}{*}{ OUM-11-5 } & 1.8 & 1.63 \\
\hline & & 2.3 & 1.71 \\
\hline & & 2.8 & 1.86 \\
\hline \multirow[t]{3}{*}{2} & \multirow[t]{3}{*}{ PDM-54 } & 1.8 & 1.83 \\
\hline & & 2.3 & 1.96 \\
\hline & & 2.8 & 2.08 \\
\hline \multirow[t]{3}{*}{3} & \multirow[t]{3}{*}{ Local } & 1.8 & 2.11 \\
\hline & & 2.3 & 2.23 \\
\hline & & 2.8 & 2.40 \\
\hline
\end{tabular}

Table.3 ANOVA of effect of speed and variety on pod loss

\begin{tabular}{|l|c|c|c|c|c|c|}
\hline Source & $\begin{array}{l}\text { Degree } \\
\text { of } \\
\text { Freedom }\end{array}$ & $\begin{array}{l}\text { Sum of } \\
\text { Square }\end{array}$ & $\begin{array}{c}\text { Mean } \\
\text { Square }\end{array}$ & F $_{\text {cal }}$ & Probability & CD \\
\hline $\begin{array}{l}\text { Factor A } \\
\text { (variety) }\end{array}$ & 2 & 1.203 & 0.602 & $155.73^{* *}$ & 0.0000 & 0.043 \\
\hline $\begin{array}{l}\text { Factor B } \\
\text { (speed) }\end{array}$ & 2 & 0.303 & 0.152 & $39.23 * *$ & 0.0000 & 0.043 \\
\hline AB & 4 & 0.005 & 0.001 & 0.3260 & & \\
\hline Error & 18 & 0.070 & 0.004 & & & \\
\hline Total & $\mathbf{2 6}$ & $\mathbf{1 . 5 8 1}$ & & & & \\
\hline
\end{tabular}

Table.4 Effect of speed on performance of pulse reaper

\begin{tabular}{|c|c|c|c|c|c|c|}
\hline SI.No & Variety & $\begin{array}{l}\text { Speed of } \\
\text { operation, } \\
\text { km/h }\end{array}$ & $\begin{array}{l}\text { Effective } \\
\text { operational } \\
\text { width, } \mathrm{mm}\end{array}$ & $\begin{array}{l}\text { TFC, } \\
\text { ha/h }\end{array}$ & $\begin{array}{l}\text { AFC, } \\
\text { ha/h }\end{array}$ & FE, \% \\
\hline \multirow[t]{3}{*}{1} & \multirow[t]{3}{*}{ OUM-11-5 } & 1.8 & 1155 & 0.208 & 0.166 & 80.09 \\
\hline & & 2.3 & 1138 & 0.261 & 0.213 & 81.38 \\
\hline & & 2.8 & 1120 & 0.313 & 0.247 & 78.89 \\
\hline \multirow[t]{3}{*}{2} & \multirow[t]{3}{*}{ PDM-54 } & 1.8 & 1158 & 0.208 & 0.166 & 79.76 \\
\hline & & 2.3 & 1143 & 0.262 & 0.211 & 80.29 \\
\hline & & 2.8 & 1123 & 0.314 & 0.247 & 78.61 \\
\hline \multirow[t]{3}{*}{3} & \multirow[t]{3}{*}{ Local } & 1.8 & 1140 & 0.205 & 0.161 & 78.70 \\
\hline & & 2.3 & 1127 & 0.259 & 0.208 & 80.58 \\
\hline & & 2.8 & 1116 & 0.312 & 0.248 & 79.51 \\
\hline
\end{tabular}


Table.5 Effect of variety on pod loss at $2.30 \mathrm{~km} / \mathrm{h}$ forward speed

\begin{tabular}{|c|c|c|c|c|c|c|c|}
\hline \multirow{2}{*}{$\begin{array}{l}\text { Pulse } \\
\text { Variety }\end{array}$} & \multirow[t]{2}{*}{ Harvesting method } & \multirow{2}{*}{$\begin{array}{l}\text { Pre- } \\
\text { harvest } \\
\operatorname{loss}\left(\mathbf{W g}_{0}\right) \text {, } \\
\mathrm{g} / \mathrm{m}^{2}\end{array}$} & \multicolumn{4}{|c|}{ Header loss, $(\mathrm{Wgt}) \mathrm{g} / \mathrm{m}^{2}$} & \multirow{2}{*}{$\begin{array}{l}\text { Header } \\
\text { loss, } \\
\frac{\mathrm{W}_{\mathrm{gt}}-\mathrm{W}_{\mathrm{g} 0}}{\mathrm{Yg}_{\mathrm{g}}} \mathrm{x} \\
{ }^{1000} \\
\%\end{array}$} \\
\hline & & & $\begin{array}{l}\text { Loose } \\
\text { grain, } \\
\left(\mathrm{Wg}_{1}\right) \\
\mathrm{g} / \mathrm{m}^{2}\end{array}$ & $\begin{array}{l}\text { Cut pod, } \\
\left(\mathrm{Wg}_{2}\right) \\
\mathrm{g} / \mathrm{m}^{2}\end{array}$ & $\begin{array}{l}\text { Uncut } \\
\text { pod, } \\
\left(\mathrm{Wg}_{3}\right) \\
\mathrm{g} / \mathrm{m}^{2}\end{array}$ & $\begin{array}{l}\text { Total loss, } \\
\mathrm{Wgt}=\left(\mathrm{Wg}_{1}+\right. \\
\left.\mathrm{Wg}_{2}+\mathrm{Wg}_{3}\right) \\
\mathrm{g} / \mathrm{m}^{2}\end{array}$ & \\
\hline \multirow{3}{*}{$\begin{array}{l}\text { OUM-11- } \\
5\end{array}$} & Pulse Reaper & 0.56 & $0 . .65$ & 0.57 & 0.50 & 1.72 & 1.71 \\
\hline & Harvesting by sickle & 0.56 & 0.60 & 0.54 & 0.0 & 1.14 & 0.85 \\
\hline & Manual uprooting & 0.56 & 0.57 & 0.53 & 0.0 & 1.10 & 0.79 \\
\hline \multirow[t]{3}{*}{ PDM-54 } & Pulse Reaper & 0.58 & 0.69 & 0.63 & 0.54 & 1.86 & 1.96 \\
\hline & Harvesting by sickle & 0.58 & 0.65 & 0.58 & 0.0 & 1.23 & 0.99 \\
\hline & Manual uprooting & 0.58 & 0.62 & 0.55 & 0.0 & 1.17 & 0.90 \\
\hline \multirow[t]{3}{*}{ Local } & Pulse Reaper & 0.61 & 0.73 & 0.68 & 0.60 & 2.01 & 2.23 \\
\hline & Harvesting by sickle & 0.61 & 0.68 & 0.63 & 0.0 & 1.31 & 1.11 \\
\hline & Manual uprooting & 0.61 & 0.65 & 0.57 & 0.0 & 1.22 & 0.96 \\
\hline
\end{tabular}

Table.6 Cost economics of developed pulse reaper for different varieties

\begin{tabular}{|c|c|c|c|c|c|c|c|}
\hline \multirow[t]{2}{*}{$\begin{array}{l}\text { Pulse } \\
\text { Variety }\end{array}$} & \multicolumn{3}{|c|}{ Pulse reaper } & \multicolumn{2}{|c|}{$\begin{array}{c}\text { Manual harvesting } \\
\text { by sickle }\end{array}$} & \multicolumn{2}{|c|}{ Manual uprooting } \\
\hline & $\begin{array}{l}\text { Cost of } \\
\text { operation, } \\
\text { Rs/h }\end{array}$ & $\begin{array}{l}\text { Time } \\
\text { required to } \\
\text { harvest, } \\
\text { h/ha }\end{array}$ & $\begin{array}{l}\text { Cost of } \\
\text { harvesti } \\
\text { ng, } \\
\text { Rs/ha }\end{array}$ & $\begin{array}{l}\text { Time } \\
\text { required to } \\
\text { harvest, } \\
\mathrm{h} / \mathrm{ha}\end{array}$ & $\begin{array}{l}\text { Cost of } \\
\text { harvesti } \\
\text { ng, } \\
\text { Rs/ha }\end{array}$ & $\begin{array}{l}\text { Time } \\
\text { required } \\
\text { to harvest, } \\
\text { h/ha }\end{array}$ & $\begin{array}{l}\text { Cost of } \\
\text { harvesting } \\
\text { Rs/ha }\end{array}$ \\
\hline OUM-11-5 & 141.37 & 4.48 & 633.33 & 128 & 3200 & 224 & 5600 \\
\hline PDM-54 & 141.37 & 4.54 & 641.81 & 132 & 3300 & 208 & 5200 \\
\hline Local & 141.37 & 4.42 & 624.85 & 124 & 3100 & 200 & 5000 \\
\hline
\end{tabular}

Table.7 Harvesting cost of Pulse reaper on the basis of annual area coverage

\begin{tabular}{|c|c|c|c|c|c|}
\hline $\begin{array}{c}\text { Annual area } \\
\text { covered by pulse } \\
\text { reaper, } \\
\text { ha/year }\end{array}$ & $\begin{array}{c}\text { Annual } \\
\text { fixed cost, } \\
\text { Rs/ha }\end{array}$ & $\begin{array}{c}\text { Variable } \\
\text { cost, } \\
\text { Rs/ha }\end{array}$ & $\begin{array}{c}\text { Total } \\
\text { cost, } \\
\text { Rs/ha }\end{array}$ & \multicolumn{2}{|c|}{ Cost of manual harvesting, Rs/ha } \\
\hline $\mathbf{1}$ & 10749 & 340 & 11089 & 3100 & Uprooting \\
\hline $\mathbf{2}$ & 5375 & 340 & 5715 & 3100 & 5000 \\
\hline $\mathbf{3}$ & 3583 & 340 & 3923 & 3100 & 5000 \\
\hline $\mathbf{4}$ & 2687 & 340 & 3027 & 3100 & 5000 \\
\hline $\mathbf{5}$ & 2150 & 340 & 2490 & 3100 & 5000 \\
\hline $\mathbf{6}$ & 1792 & 340 & 2132 & 3100 & 5000 \\
\hline $\mathbf{7}$ & 1536 & 340 & 1876 & 3100 & 5000 \\
\hline $\mathbf{8}$ & 1344 & 340 & 1684 & 3100 & 5000 \\
\hline $\mathbf{9}$ & 1194 & 340 & 1534 & 3100 & 5000 \\
\hline $\mathbf{1 0}$ & 1075 & 340 & 1415 & 3100 & 5000 \\
\hline
\end{tabular}


Fig.1 Developed reaper

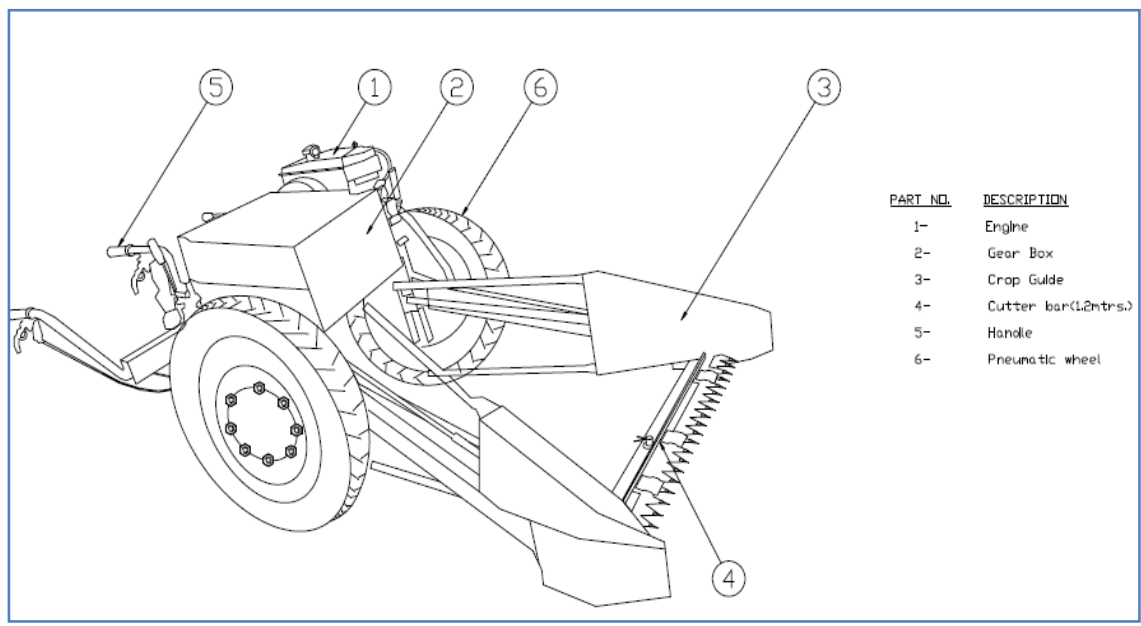

Fig.2 Harvesting of green gram with the developed reaper

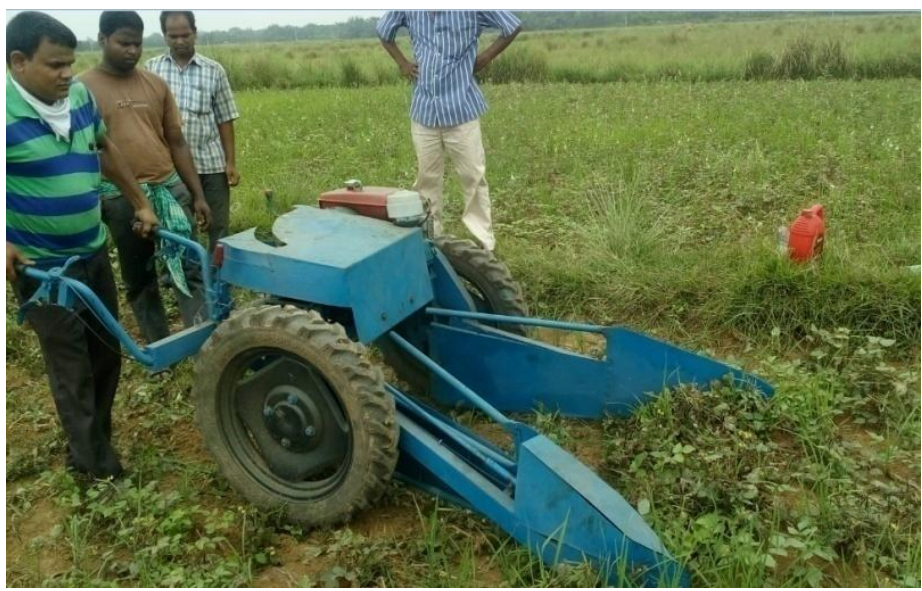

Fig.3 Effect of machine speed on pod loss

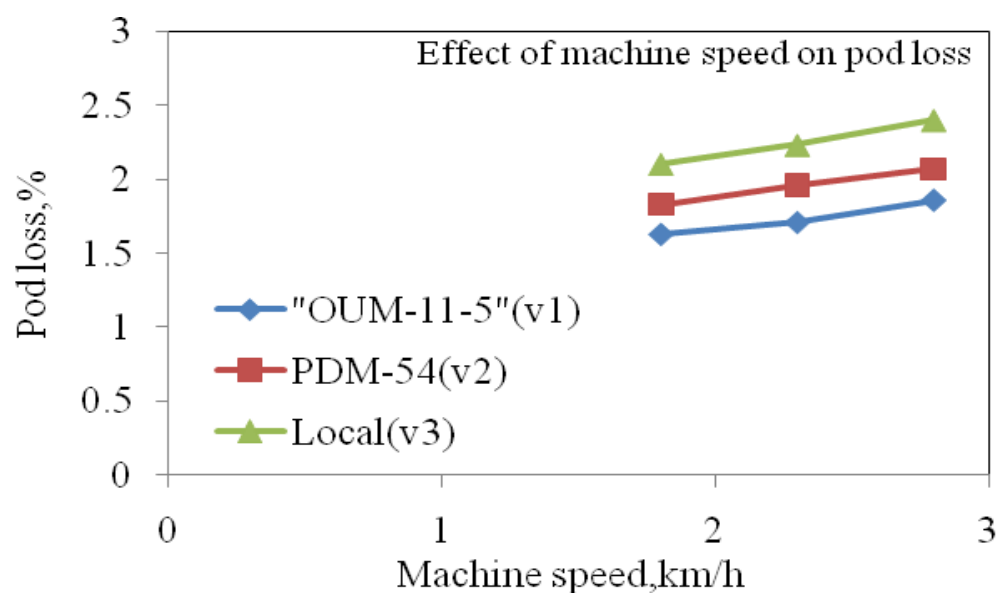


Fig.4 Effect of pod moisture content on pod losses

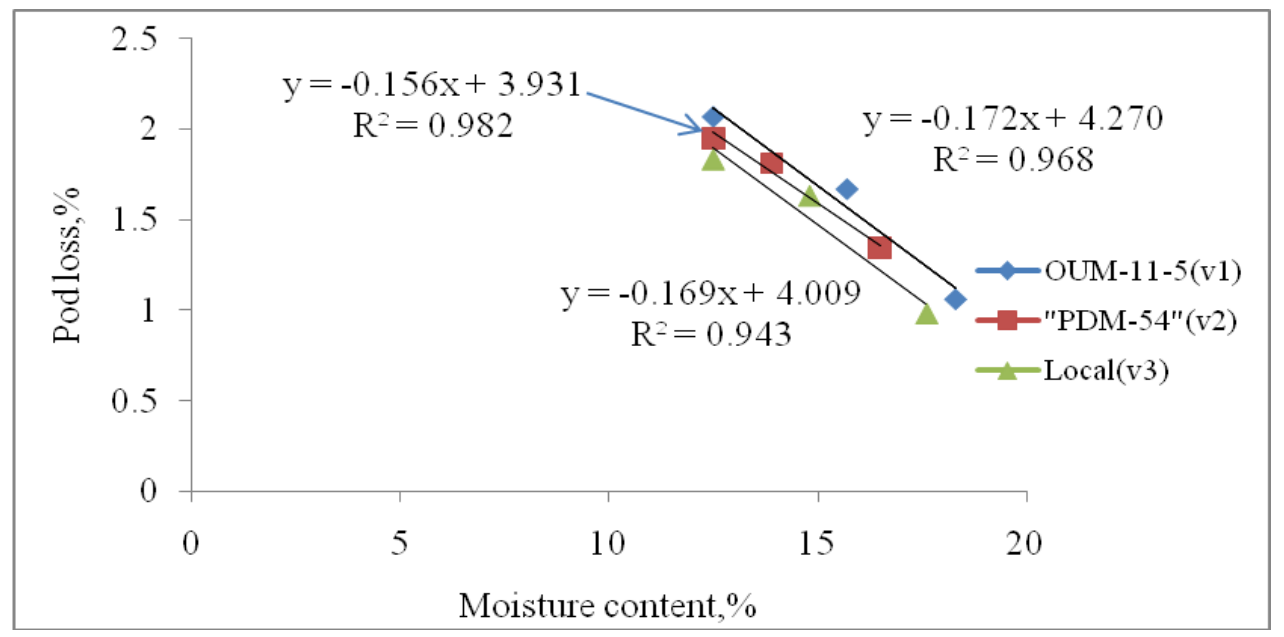

Fig.5 Effect of annual use on harvesting cost of pulse reaper

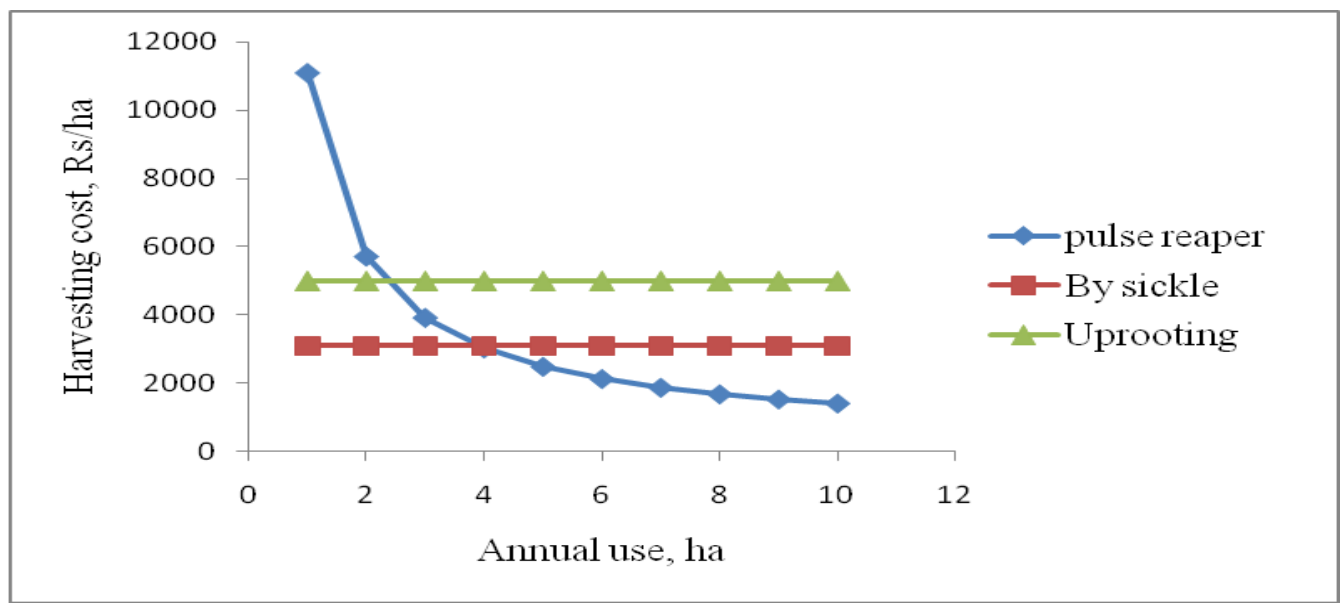

\section{Effect of pod moisture content on pod loss}

The effect of pod moisture content on pod loss at $2.30 \mathrm{~km} / \mathrm{h}$ forward speed of machine was studied and is presented in Figure 4. The highest pod losses ranging from 1.06 to $2.07 \%$ were observed for OUM-11-5 variety at moisture content ranging from 12.5 to $18.3 \%$. The lowest pod losses of 0.98 to $1.83 \%$ were observed for Local variety at moisture level 13.9 to $20 \%$.. The lower pod loss in local variety as compared to OUM 11-5 may be due to its comparatively higher pod moisture content at the time of harvesting. In general, the pod loss increases with decrease in pod moisture content.

\section{Cost economics}

The cost of operation of the pulse reaper was found to be Rs 141.37 per hour. The cost of harvesting per hectare was calculated by considering the time required for harvesting per hectare and is presented in Table 6. It is found that the minimum cost of harvesting (Rs $5000 /$ ha) observed for local variety while the higher cost of Rs 5600/ha observed for OUM11-5 variety. Lowest cost of harvesting for local variety may be due to less time requirement to harvest the local variety as compared to other varieties. 


\section{Break even use}

The pulse reaper has high annual fixed cost which is gradually decreased with increase in area of coverage per year (Table 7). The minimum area that the pulse reaper should cover so that its cost of harvesting per hectare equals to that of manual harvesting is the break even point. The relationship between the total annual harvesting cost per hectare and annual harvested area is shown in Table 7. It was found that for the pulse reaper the annual coverage area is 3.9 ha so as to make the harvesting cost equal to that of conventional manual harvesting by sickle (Fig. 5). While compared with the harvesting by uprooting, annual coverage is 2.3 ha at which the harvesting cost equal to this uprooting method.

It is concluded as follows:

It is observed that the highest effective field capacity of $0.264 \mathrm{ha} / \mathrm{h}$ was with the local variety at $2.80 \mathrm{~km} / \mathrm{h}$ speed while the lowest field capacity of $0.170 \mathrm{ha} / \mathrm{h}$ at $1.80 \mathrm{~km} / \mathrm{h}$ speed for the same variety. The highest field efficiency of $82.48 \%$ was found to be with local variety at $2.30 \mathrm{~km} / \mathrm{h}$ speed while the lowest field capacity of $78.54 \%$ was with OUM-11-5 variety at $2.80 \mathrm{~km} / \mathrm{h}$ speed.

The highest pod losses ranging from 0.96 to $2.23 \%$ were observed for local variety as the speed varied from 1.80 to $2.80 \mathrm{~km} / \mathrm{h}$. In general, the pod loss increases with decrease in pod moisture content and increase in speed for all the three varieties.

The cost of operation of the pulse reaper was found to be Rs 141.37 per hour. The cost of harvesting per hectare was calculated by considering the time required for harvesting per hectare. It is found that the minimum cost of harvesting (Rs 5000/ha) observed for local variety while the higher cost of Rs 5600/ha observed for OUM-11-5 variety.

It was found that for the pulse reaper the annual coverage area is 3.9 ha (break even point) so as to make the harvesting cost equal to that of conventional manual harvesting by sickle. While compared with the harvesting by uprooting, annual coverage is 2.3 ha at which the harvesting cost equal to this uprooting method.

\section{References}

Gowda Laxmipathi CL, Srinivasan S., Gaur PM and Saxena KB. 2013. Enhancing the Productivity and Production of Pulses in India.

Anonymous, 2013. IIPR Vision 2030. Printed \& Published by the Director, Indian Institute of Pulses Research (ICAR), Kanpur208024.

Anonymous, 2013. Economic survey, 2012-13, Department of Planning and Coordination, Govt. of Odisha.

Srivastava AK, Goering CE, Rohrbach RP 2006. Engineering Principles of Agricultural Machines. 2ndedn. American Society of Agricultural Engineers, St Joseph MI, USA, 49085-9659

Manian, R., Natrajanmurthy, K., Chinnanchetty, G. and Kumar, V.J.F. 1987. Evaluation of IRRI transplanter in clay loam soil. J. Agric. Engg. 24 (2): 127-137.

Singh, G. and Hussain, U.K. 1983. Modification and testing of a manual rice transplanter. AMA. 14(2): 25-30.

\section{How to cite this article:}

Shibanee Maharana, A.K. Goel, D. Behera and Mahapatra, M. 2018. Development and Evaluation of a Self Propelled Pulse Reaper. Int.J.Curr.Microbiol.App.Sci. 7(11): 1983-1991. doi: https://doi.org/10.20546/ijcmas.2018.711.225 